\title{
Mesurments of Photosynthesis AND TrANSPIRATION ON APPLE TREES
}

\author{
KELC, D.; VINDIS, P. \& LAKOTA, M.
}

Abstract: Measurements of photosynthetic activity and transpiration were followed on 12-year old 'Golden Delicious' apple trees (Malus domestica Borkh.) grown in the experimental orchard of the Biotechnical Faculty. We tested also trees response to early defruting. The treatments encompassed fruiting and non-fruiting trees. Each treatment involved four trees. Trees from the picked treatment were defruited in August. The photosynthetic activity and transpiration of spur leaves were measured 5 times in the season. For the analysis we used LICOR-6400 removeable measurement gas exchange system at the concentration $350 \mu \mathrm{mol} \mathrm{mol}{ }^{-1} \mathrm{CO}_{2}$. A clear, significant decrease in photosynthetic activity of leaves and transpiration was noted in nonfruiting trees at second and third measurement, compared to fruiting trees.

Key words: photosynthesis, mesurements, transpiration, apple, gas exchange
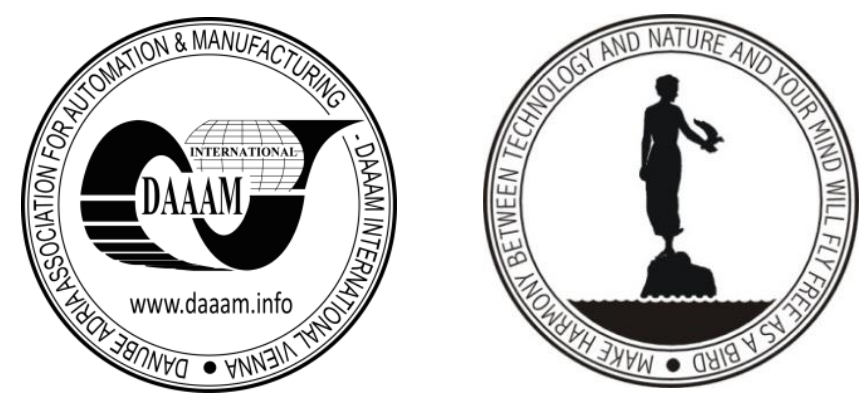

Authors' data: Msc. Kelc, D[amijan]; Assist. Dr. Vindis, P[eter]; Assoc. Prof. Lakota, M[iran]; University of Maribor, Faculty of Agriculture and Life Sciences, Pivola 10, SI-2311, Hoce, Slovenia, damijan.kelc@um.si, peter.vindis@um.si, miran.lakota@um.si

This Publication has to be referred as: Kelc, D[amijan]; Vindis, P[eter] \& Lakota, M[iran] (2015). Mesurments of Photosynthesis and Transpiration on Apple Trees, Chapter 18 in DAAAM International Scientific Book 2015, pp.199-208, B. Katalinic (Ed.), Published by DAAAM International, ISBN 978-3-902734-05-1, ISSN 17269687, Vienna, Austria

DOI: 10.2507/daaam.scibook.2015.18 
Kelc, D.; Vindis, P. \& Lakota, M.: Mesurments of Photosynthesis and Transpiratio...

\section{Introduction}

The ability of green plants is production of organic substances from atmospheric carbon dioxide, water and solar energy. The process is known as photosynthesis (Friedrich and Fischer, 2000). Pigment chlorophyll in the plants convert light energy into chemical energy which can be stored in the molecular bonds of organic molecules (e.g., sugars). Carbon dioxide from the air and water in the presence of sunlight produce sugars. Oxygen is released as a by-product of photosynthesis out through the stomata (figure 1) (Hall and Rao, 1994). Photosynthesis generates the majority of energy and food on the earth.

The following equation describes the process of net photosynthesis:

$$
6 \mathrm{CO}_{2}+6 \mathrm{H}_{2} \mathrm{O}+\text { Light Energy }=\mathrm{C}_{6} \mathrm{H}_{12} \mathrm{O}_{6}+6 \mathrm{O}_{2}
$$

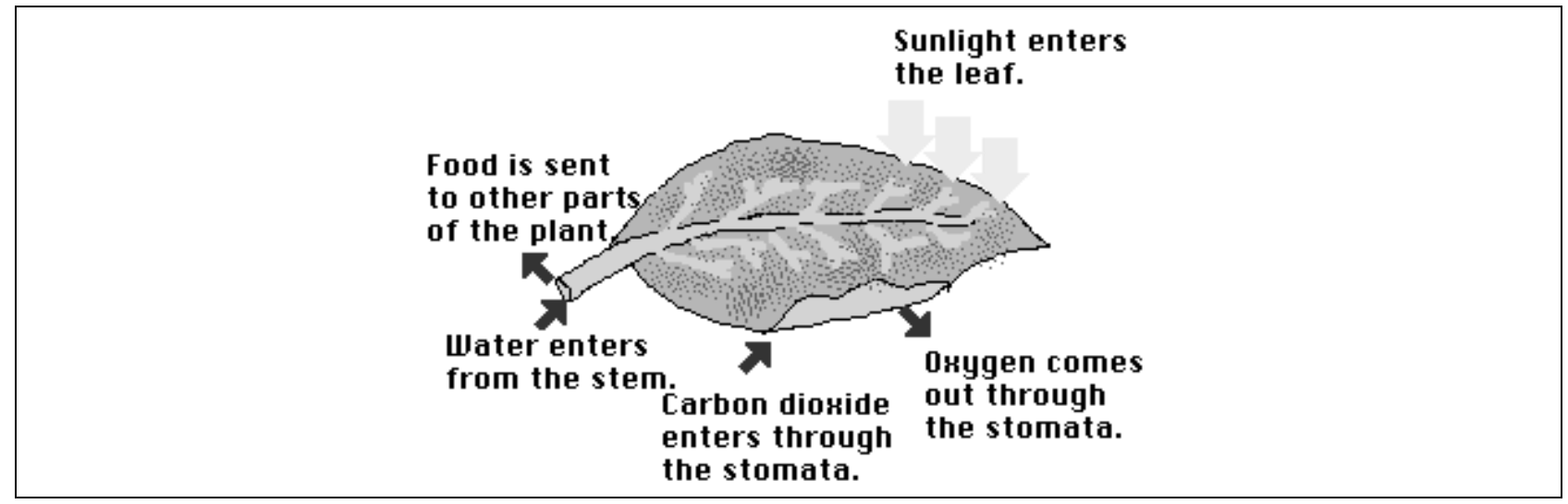

Fig. 1. Leave involved in the process of photosynthesis

Photosynthetic productivity depends on external and internal factors (Stampar et al., 1999). The external factors include: intensity of lighting, temperature changes and plant available water (Faust, 1989). The most important internal factor are fruits and other assimilates consumers (Faust, 1989; Paul and Foyer 2001).

From about $1.3 \mathrm{kWm}^{-2}$ of solar energy reaching the earth, only $5 \%$ is converted to a carbohydrate in the process of photosynthesis. This is due to the fact that the wavelength of light are too long, or too short to be absorb in the photosynthetically active pigments. Photosynthetically active radiation (PAR), which is useful for photosynthesis, has a wavelength from 400 and $700 \mathrm{~nm}$. Approximately 85 to $90 \%$ of the PAR radiation is absorbed in the sheet, and the rest is reflected or penetrates the sheet (Taiz and Zeiger, 1998). Optimal temperature for the photosynthesis of apple trees is between 20 and $30{ }^{\circ} \mathrm{C}$ at the optimal PAR radiation (Faust, 1989; Friedrich in Fischer, 2000).

Assimilates consumers stimulates the photosynthesis activity. Fruits don't stimulates leaves which are far away from each other (Faust, 1989; Friedrich and Fischer, 2000).

Photosynthesis is closely related to the plant gas exchange with the environment. This exchange is mainly performed through the stomatal apparatus. In addition to the 
exchange of gases allows regulation of the water status of the plants and had the effect on turgor (Faust, 1989).

\section{Photosynthesis depending of the fruits on the trees}

Fruiting apple trees can greatly reduce leaf surface, compared with trees without fruits, although the total amount of dry matter content of apple at maturity of the fruit is often higher in the tree with fruits. This reflects higher photosynthetic efficiency of the leaves of trees with fruits. Research productivity have shown that the growth of plants with fruits, is reduced as the carbohydrates are used for the development of fruit. Experiments with ${ }^{14} \mathrm{CO}_{2}$ have shown that the fetus acts as a powerful sink and caused a very efficient transportation of products of photosynthesis from the leaves to the fruit (Faust, 1989). The ripeness of the fruit induces the movement of carbohydrates and accelerate the movement of nitrogen, phosphorus and potassium. Photosynthesis of the apple trees in the autumn is influenced by non-stomatal factors such as chlorophyll, carbohydrates and nutrients. In this time, photosynthesis primary limiting environmental factors such as salt, reduced lighting, temperature and shorter days (Tartachnyk and Blanke, 2001; Dobren et al., 2008; Marinescu et al., 2008).

Fujii and Kennedy (1985) reported of two periods of increased photosynthetic activity of apple tree. The first period of increased photosynthetic activity is at the time of flowering, where have the leaves of flowering shoots up to $25 \%$ greater intensity of photosynthesis, compared with the leaves of vegetative shoots. The second period is between July and September, after the development of the leaf mass and after the rapid growth of the fruit. The highest photosynthetic activity was recorded in the leaves very close to the fruits, and less photosynthetic activity in the leaves on the shoots without fruit.

Giuliani et al. (1997) noted that higher yield had greater impact on the assimilation ability of apple trees while the trees without fruit shown lower photosynthetic activity. The same authors have concluded that the measured gas exchange of trees with the fruits is $20 \%$ higher than in the trees without fruits.

\subsection{Transpiration depending of the fruits on the trees}

Transpiration of the leaves depends on two main factors. First is the difference in the concentration of water vapour between the interior of the leaves and the ambient air. The second is diffusion resistance (Friedrich and Fischer, 2000).

The presence of fruits reducing the growth of apple trees and other fruit plants. Fruits may affect the water balance of the trees, resulting in reduced shoots growth. Studies on peach, plum and apple trees suggesting that the presence of the fruits have a positive effect on stomatal conductance. Trees that are over three years yielded twice, with a minimum leaf area, have the highest value of transpiration, compared to trees without fruits, which has the largest leaf area (Faust, 1989).

Fruits on trees increase the level of transpiration regardless of the month in which

the fruits are removed. At trees with fruits stomatal apparatus is open a longer time. It 
Kelc, D.; Vindis, P. \& Lakota, M.: Mesurments of Photosynthesis and Transpiratio...

is open wider and earlier in the morning and stays open longer in the afternoon and evening (Blanke, 1997).

\section{Description of the measurement procedure}

General parts of a photosynthesis gas exchange system are leaf chamber, flow meter and means of generating and controlling air flow over the leaf. It exists closed and open gas exchange systems.

In closed systems the signal from the sample cell is compared to the zero gas reference signal to provide an absolute measurement of $\mathrm{CO}_{2}$ concentration. A leaf is enclosed in a chamber, sealed to avoid gas exchange with the atmosphere, and the rate at which the $\mathrm{CO}_{2}$ and $\mathrm{H}_{2} \mathrm{O}$ concentration changes in the chamber are monitored.

Open systems are configured to allow air from a single source to enter both the analysis and reference lines. Air is continuously passed through the leaf chamber (to maintain $\mathrm{CO}_{2}$ in at fixed concentration) and measurements of photosynthesis and transpiration are based on the differences in $\mathrm{CO}_{2}$ and $\mathrm{H}_{2} \mathrm{O}$ in an air stream that is flowing into the leaf cuvette (reference cell) compared to the air stream flowing out of it (sample cell). The rate of $\mathrm{CO}_{2}$ uptake is used to assess the rate of photosynthetic carbon assimilation, while the rate of water loss is used to assess the rate of transpiration (counted on a leaf area basis) (Long et al., 1996).

LI-6400 (figure 2) is an open system design photosynthetic gas exchange system.

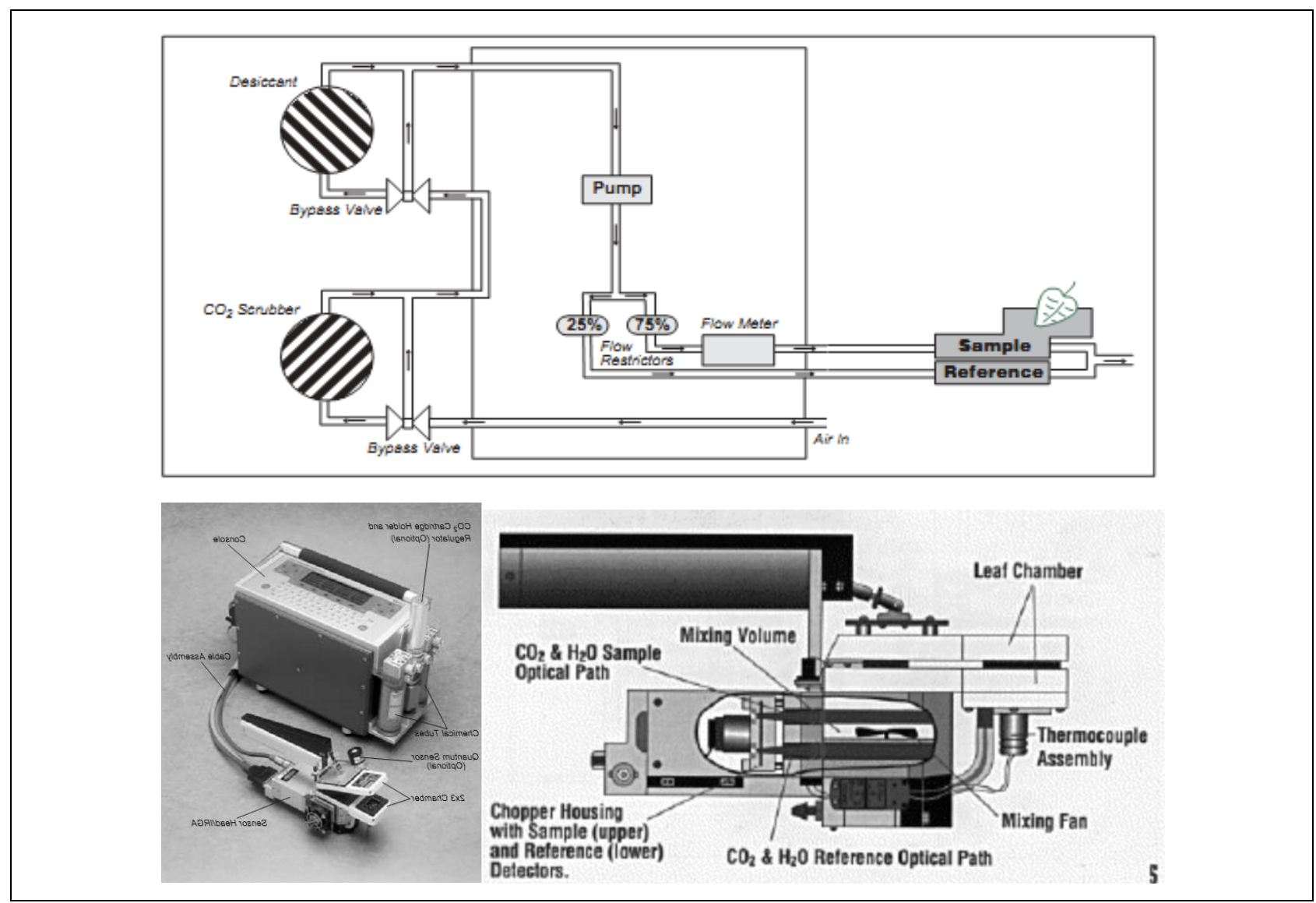

Fig. 2. Shematic LI-6400, device and the sensor head 
IRGAs $\left(\mathrm{H}_{2} \mathrm{O}\right.$ and $\left.\mathrm{CO}_{2}\right)$ are in the sensor head that gives a possibility for a tight control of conditions in the leaf chamber response to leaf changes. The incoming air stream can be conditioned for $\mathrm{CO}_{2}$ concentration, humidity and temperature. There are chemical tubes for scrubbing $\mathrm{CO}_{2}$ and $\mathrm{H}_{2} \mathrm{O}$, and air can be diverted through these tubes in any proportion desired. $\mathrm{CO}_{2}$, however, is best controlled by scrubbing all of it from the incoming air, and using $\mathrm{CO}_{2}$ source to provide a stable concentration at the desired value (optional $\mathrm{CO}_{2}$ injection system). The measurement systems LI-6400/LI-6400XT (LI-COR, Lincoln, Nebraska, USA) quickly became the world leader in photosynthesis measurement systems. It is the most referenced photosynthesis system in scientific publications (LI-COR, 2004).

\section{Material and method}

\subsection{Material}

Measurements were made the summer and autumn at 12 years old apple trees, cv. 'Golden Delicious' (figure 3) in the experimental field of the Biotechnical Faculty. Basis for vaccination was M9. Treatments including fruiting and non-fruiting trees. Fruits were removed after the control measurements of photosynthesis. Each treatment involved four trees. When dealing with trees without fruit, fruits were removed in August.

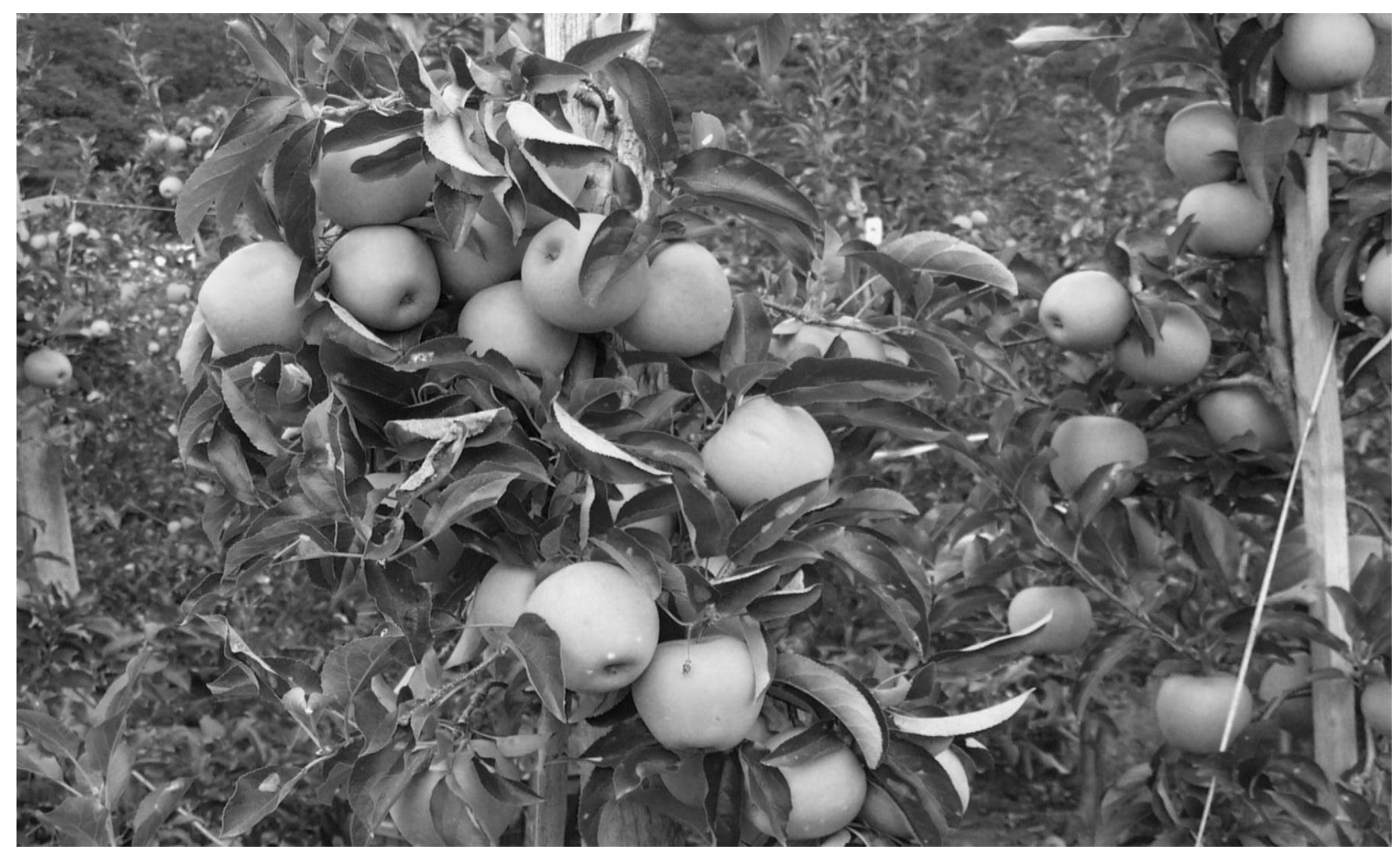

Fig. 3. Fruiting apple tree, cultivar 'Golden Delicious'

\subsection{Measurements of photosynthesis and transpiration}

Photosynthetic activity and transpiration of leaves were measured five times during the season (Table 1). On each tree we have chosen two leaves, which later 
Kelc, D.; Vindis, P. \& Lakota, M.: Mesurments of Photosynthesis and Transpiratio...

served in measurements. Each leave was chosen on the other side of the tree. The control measurement was performed 12 days before the removal of the fruits. A second measurement was carried out 7 days after the fruits removal, the third 16 days, the fourth 37 days and fifth, 61 days after the fruits has been removed. When dealing with trees without fruit, fruits were removed on 13 of August.

For the measurements we used moved photosynthetic gas exchange system Li6400 (LICOR, Lincoln, USA). Measurements were made at the concentration 350 $\mu \mathrm{mol} \mathrm{mol}{ }^{-1} \mathrm{CO}_{2}$ and at the lighting $1500 \mu \mathrm{mol} \mathrm{m}^{-2} \mathrm{~s}^{-1} \mathrm{PFD}$. The temperature of the leaves were adjusted in the cuvette on $22-23^{\circ} \mathrm{C}$.

\subsubsection{Data processing}

Data measurements were statistically analysed by analysis of variance (ANOVA) with the help of the program Statgraphics Plus 4.0. Differences between treatments were tested using multiple comparison tests such as LSD and Duncan test at the risk $\alpha$ $<0.05$.

\section{Results with discussion}

\subsection{Net photosynthesis}

Figure 4 shows net photosynthesis in 'Golden Delicious'. The measurements shown averages with standard deviation.

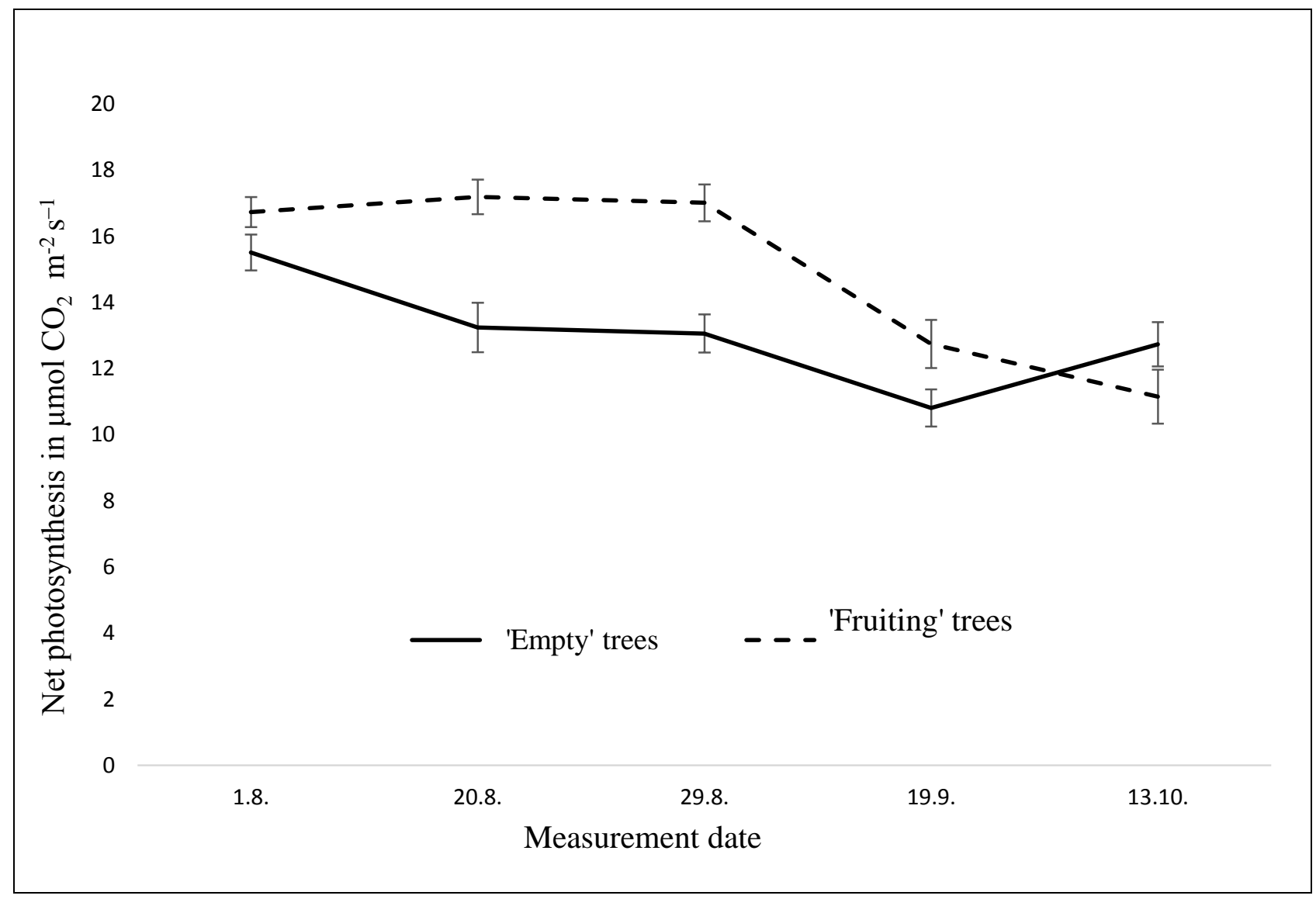

Fig. 4. Net photosynthesis in 'Golden Delicious' to deal with 'fruiting' trees and 'empty' trees in $\mu \mathrm{mol} \mathrm{CO} \mathrm{CO}^{-2} \mathrm{~s}^{-1}$ 
Table 1 shown the value of the standard deviation for net photosynthesis measurements. Measurements in the line marked with the same letter do not differ significantly according to LSD test at $\alpha=0.05$.

\begin{tabular}{|c|c|c|}
\hline \multicolumn{3}{|c|}{ Net photosynthesis in $\boldsymbol{\mu m o l ~} \mathbf{C O}_{\mathbf{2}} \mathbf{~ m}^{-\mathbf{2}} \mathbf{s}^{\mathbf{- 1}}$} \\
\hline Measurements & 'Empty' trees & 'Fruting' trees \\
\hline 1.8. & $15,51 \pm 0,54 \mathrm{a}$ & $16,73 \pm 0,45 \mathrm{a}$ \\
\hline 20.8 & $13,24 \pm 0,75 \mathrm{a}$ & $17,19 \pm 0,52 \mathrm{~b}$ \\
\hline 29.8. & $13,06 \pm 0,58 \mathrm{a}$ & $17,01 \pm 0,56 \mathrm{~b}$ \\
\hline 19.9 & $10,81 \pm 0,56 \mathrm{a}$ & $12,74 \pm 0,73 \mathrm{a}$ \\
\hline 13.10 & $12,73 \pm 0,67 \mathrm{a}$ & $11,15 \pm 0,82 \mathrm{a}$ \\
\hline
\end{tabular}

Tab. 1. Net photosynthesis in $\mu \mathrm{mol} \mathrm{CO}_{2} \mathrm{~m}^{-2} \mathrm{~s}^{-1}$, for Golden Delicious' with fruts and without fruits

\subsection{Transpiration}

Figure 5 shows transpiration in $\mu \mathrm{mol} \mathrm{CO} \mathrm{CO}^{-2} \mathrm{~s}^{-1}$ in 'Golden Delicious'.

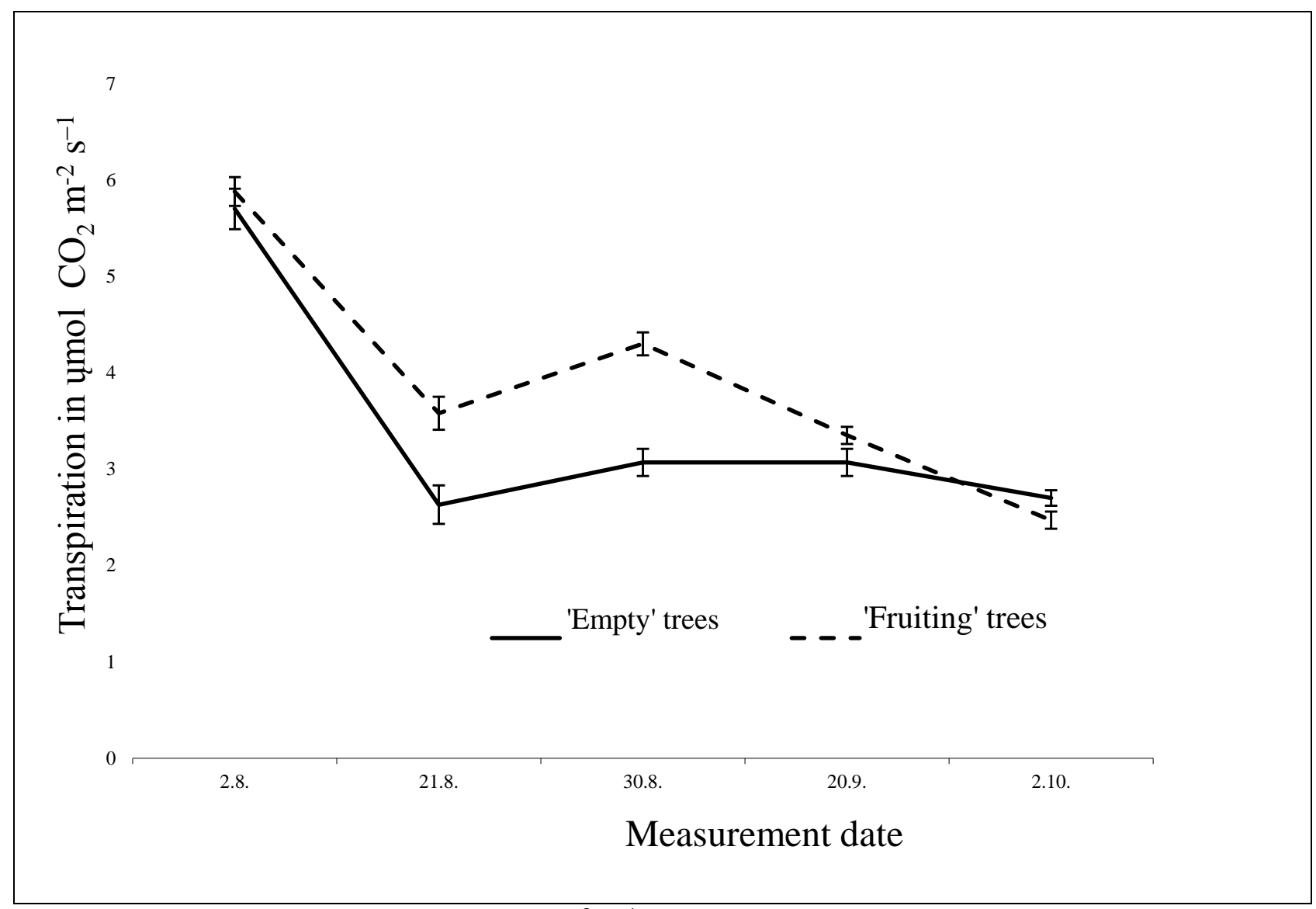

Fig. 5. Transpiration in $\mu \mathrm{mol} \mathrm{CO}_{2} \mathrm{~m}^{-2} \mathrm{~s}^{-1}$ in 'Golden Delicious' for trees with and without fruits 
Kelc, D.; Vindis, P. \& Lakota, M.: Mesurments of Photosynthesis and Transpiratio...

All the transpiration measurements with standard deviation are gathered in the table 2. Measurements in the line marked with the same letter do not differ significantly according to LSD test at $\alpha=0.05$ (Table 2).

\begin{tabular}{|c|c|c|}
\hline \multicolumn{3}{|c|}{ Transpiration in $\boldsymbol{\mu m o l ~} \mathbf{C O}_{2} \mathbf{~ m}^{-2} \mathbf{s}^{-1}$} \\
\hline Measurements & 'Empty' trees & 'Fruting' trees \\
\hline 2.8. & $5,70 \pm 0,21 \mathrm{a}$ & $5,88 \pm 0,15 \mathrm{a}$ \\
\hline 21.8. & $2,63 \pm 0,20 \mathrm{a}$ & $3,58 \pm 0,17 \mathrm{~b}$ \\
\hline 30.8. & $3,07 \pm 0,14 \mathrm{a}$ & $4,30 \pm 0,12 \mathrm{~b}$ \\
\hline 20.9. & $3,07 \pm 0,14 \mathrm{a}$ & $3,35 \pm 0,09 \mathrm{a}$ \\
\hline 2.10. & $2,70 \pm 0,08 \mathrm{a}$ & $2,47 \pm 0,09 \mathrm{a}$ \\
\hline
\end{tabular}

Tab. 2. Transpiration in $\mu \mathrm{mol} \mathrm{CO}_{2} \mathrm{~m}^{-2} \mathrm{~s}^{-1}$, for 'Golden Delicious' with fruits and without fruits and the value of the standard deviation

'Empty' trees have lower transpiration as a fruiting trees in all four measurements. Only at the last measurement is a slightly higher transpiration at the 'empty' trees. This is exactly the same as in the measurement of photosynthesis, when have 'empty' trees only at the last measurement higher net photosynthesis. As we have seen, the higher net photosynthesis also associated with higher transpiration. We observed statistically significant differences in the second and third treatment. That is the same as in the photosynthesis measurements. Maximum transpiration was measured at the first measurement and the maximum difference between 'empty' and 'fruiting' trees was observed in the third measurement.

The first measurement of the net photosynthesis, which was performed 12 days before we removed the fruits of the trees, is highly uniform in both groups of trees. Then the trees were divided into the 'fruiting' and 'empty' trees. At the time of the second measurement, it was one week after the removal of the fruits, and at the time of the third measurement, 16 days after the removal of fruits, we observed a statistically significant higher level of the net photosynthesis and transpiration, comparing both groups of trees. 'Fruiting' trees have higher net photosynthesis and transpiration as 'empty' trees. These results support the idea that photosynthesis is stimulated with fruits, and that the fruits act as a sink for assimilates. We can conclude that is higher photosynthesis associated with higher transpiration. A month later, in the fourth measurement, the difference between two groups of trees were no longer statistically significant. Veberic et al. (2002) reported that are fruits of 'Golden Delicious' strong sink for carbohydrates synthesized until full ripening. Later the importance of fruits as a sink for sugars is reduced.

This corresponds to a study made by Blanke (1997), who says that fruits increase the level of transpiration regardless of the month in which the fruits are removed and 
that the trees with fruits has a stomatal apparatus open for a longer time. This also means greater evaporation of water from the leaves and the higher level of transpiration. The presence of fruit therefore has a significant impact on photosynthesis. The last measurement of photosynthesis and transpiration show that 'fruitting' trees has lower values, which confirms the role of fruit as a sink in the regulation of photosynthesis and transpiration. A similar findings was noted by Wibbe and Blanke (1995), who argue that the short-term storage of carbohydrates in the leaves, such as starch and sucrose, has the effect of reducing photosynthetic activity during apple ripening.

\section{Conclusions}

In the experimental field of the Biotechnical Faculty in Ljubljana, was at 12 years old apple trees cv. 'Golden Delicious', performed an experiment in which we evaluated the intensity of photosynthesis, depending on the presence of fruits. The experiment consisted of two treatments, with 'fruiting' trees and 'empty' trees. Each treatment involved four trees. The activity of photosynthesis and transpiration were measured five times in a year. In the second half of August, it was clear reduction in photosynthetic activity and transpiration in the leaves of the 'empty' trees. Both, the second and third measurements of photosynthesis and transpiration of 'fruiting' trees is statistically significantly higher. Photosynthesis and transpiration have a very similar path of growth and decline during the experiment. We can conclude that they are in a close relationship. More fruits on the tree involve higher photosynthesis and consequently higher transpiration. With higher production trees need more sophisticated growing technology to avoid unexpected situations, like water stress, high temperatures, etc. Further experimental work should be made on other fruiting species with different treatments (with or without fruits, in a dry or wet season, in a different growing technologies and stress situations), or even on other agriculture crops. Energy crops are one interesting group of them, to discover the productivity of photosynthesis in relationships with energy output of the plants. Evaluation of crops and production simulation model should be made similar as Vindis et al. (2010) made for biogas production.

\section{References}

Blanke, M.M. (1997). Effect of fruit load on whole tree carbon assimilation, dark respiration, and water relations in apple. Acta Hort., 451: 313-317, ISSN 0567-7572. Dobren, F.A.; Dumitrescu, C.D.; Istrat, N. \& Marinescu, S.A. (2008). Influence of the Photosynthesis on the Pollution Wtih Carbon Dioxide in Timisoara, Annals of DAAAM for 2008 \& Proceedings of the 19th International DAAAM Symposium, 22-25th October 2008, Trnava, Slovakia, ISSN 1726-9679, ISBN 978-3-901509-68-1, Katalinic, B. (Ed.), pp. 0369-0370, Published by DAAAM International Vienna, Vienna 
Kelc, D.; Vindis, P. \& Lakota, M.: Mesurments of Photosynthesis and Transpiratio...

Faust, M. (1989). Physiology of temperate zone fruit trees. ISBN 0-471-81781-3, USA, John Wiley \& Sons: 338 pg

Friedrich, G. \& Fischer, M. (2000). Physiologische grundlagen des obstbaues. 3. Ausgabe. ISBN 3-8001-3475-6, Stuttgart, Eugen Ulmer Verlag: 512 pg

Fujii, J.A. \& Kennedy R.A. (1985). Seasonal Changes in the Photosynthetic Rate in Apple Trees. ISSN 1532-2548, Plant Physiol., 78: 519-524

Giuliani, R.; Corelli-Grappadelli, L. \& Magnanini E. (1997). Effects of crop load on apple photosynthetic responses and yield. ISSN 0567-7572, ISBN 978-90-6605-5742, Acta Hort., 451: 303-311

Hall, D.O \& Rao. K.K. (1994). Photosynthesis. ISBN 0-521-43622-2, 5th Edition, Cambridge

LI-COR, (2004). Using the LI-6400 Portable Photosynthesis System. Version 5 (2004) LI-COR, Biosciences, Inc. Lincoln, NE, USA

Long, S.P.; Farage P.K. \& Garcia, R.L. (1996). Measurement of leaf and canopy photosynthetic CO2 exchange in the field. ISSN 1460-2431, Journal of Experimental Botany 47: 1629-1642

Marinescu, S.A.; Rusnac, L. \& Dobren, F.A. (2008). Influences of the Growth of the Carbon Dioxide Emissions Depending on the Process of Photosynthesis in Timisoara, Annals of DAAAM for 2008 \& Proceedings of the 19th International DAAAM Symposium, 22-25th October 2008, Trnava, Slovakia, ISSN 1726-9679, ISBN 978-3901509-68-1, Katalinic, B. (Ed.), pp. 0761-0762, Published by DAAAM International Vienna, Vienna

Paul, M.J. \& Foyer, C.H. (2001). Sink regulation of photosynthesis. ISSN 0022-0957, Journal of Experimental Botany, 52: 1383-1400

Stampar, F.; Hudina, M.; Usenik, V., Šturm, K.; Viršček Marn, M. \& Batič, F. (1999). Influence of leaf area on net photosynthesis, yield and flower bud formation in apple (Malus domestic Borkh.). ISSN 0079-2047, Phyton (Horn, Austria), 39, 3: 101-106 Taiz, L. \& Zeiger, E. (1998). Plant Physiology. 2. Issue. ISBN 0-87893-856-7, USA, Sinauer Associates, Inc.: 792 pg

Tartachnyk, I. \& Blanke, M.M. (2001). Environmental effects on apple tree physiology. ISSN 0567-7572, Acta Hort., 557: 465-472

Veberic, R.; Stampar, F. \& Vodnik, D. (2002). Autumn photosynthesis of 'Golden Delicious' apple trees-the effect of picking and fertilisation treatment. ISSN: 14698137, Gartenbauwissenschaft, 67, 3: 92-98

Vindis, P.; Stajnko, D.; Berk, P. \& Lakota, M. Qualitative multi-criteria evaluation of energy crops. V: KATALINIĆ, Branko (ur.). DAAAM International scientific book 2010, (DAAAM International scientific book, ISSN 1726-9687). Vienna: DAAAM International Publishing, 2010, 99-116

Wibbe, M.L. \& Blanke, M.M. (1995). Effects of defruting on source-sink relationship, carbon budget, leaf carbohydrate content and watwr use efficiency of apple trees. ISSN 0137-5881, Physiologia Plantarum, 94: 529-533 